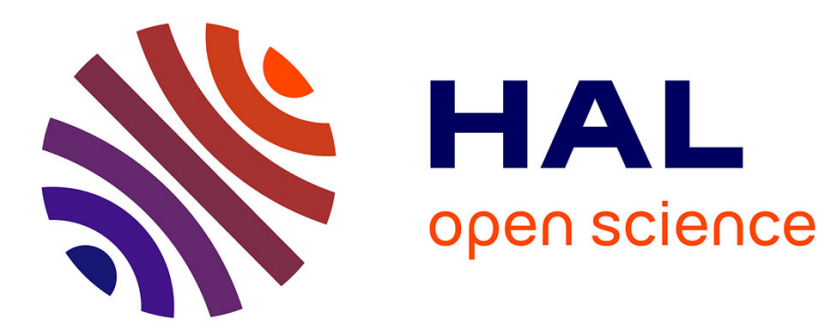

\title{
GPS tracking devices reveal foraging strategies of Black-legged Kittiwakes
}

Jana Kotzerka, Stefan Garthe, Scott A. Hatch

\section{To cite this version:}

Jana Kotzerka, Stefan Garthe, Scott A. Hatch. GPS tracking devices reveal foraging strategies of Black-legged Kittiwakes. Journal für Ornithologie = Journal of Ornithology, 2009, 151 (2), pp.459467. 10.1007/s10336-009-0479-y . hal-00568362

\section{HAL Id: hal-00568362 https://hal.science/hal-00568362}

Submitted on 23 Feb 2011

HAL is a multi-disciplinary open access archive for the deposit and dissemination of scientific research documents, whether they are published or not. The documents may come from teaching and research institutions in France or abroad, or from public or private research centers.
L'archive ouverte pluridisciplinaire HAL, est destinée au dépôt et à la diffusion de documents scientifiques de niveau recherche, publiés ou non, émanant des établissements d'enseignement et de recherche français ou étrangers, des laboratoires publics ou privés. 
1 Journal of Ornithology 00: 000-000, 2009

2

3 GPS tracking devices reveal foraging strategies of Black-legged Kittiwakes

Jana Kotzerka, Stefan Garthe and Scott A. Hatch

J. Kotzerka (correspondence) and S. Garthe, Research and Technology Center Westcoast

Büsum, University of Kiel, Hafentörn 1, 25761 Büsum, Germany, E-mail: kotzerka@ftz-

west.uni-kiel.de, Phone: ++49-4834-604142, Fax: ++49-4834-604199

S. A. Hatch, U.S. Geological Survey, Alaska Science Center, 4210 University Drive,

11 Anchorage, Alaska 99508, USA

12

13 Black-legged Kittiwakes Rissa tridactyla are the most abundant gull species in 14 the world but some populations have declined in recent years, apparently due to food shortage. Kittiwakes are surface feeders and thus can compensate for low food availability only by increasing their foraging range and/or devoting more time to foraging. The species is widely studied in many respects, but long-distance foraging and the limitations of conventional radio telemetry have kept this vital activity largely out of view. Development of GPS loggers is advancing rapidly. With devices as small as $8 \mathrm{~g}$ now available it is possible to use this technology for tracking relatively small species of oceanic birds like kittiwakes. Here we present the first results of GPS telemetry applied to Black-legged Kittiwakes in 2007 in the North Pacific. All but one individual 
foraged in the neritic zone north of the island. Three birds performed foraging trips only close to the colony (within $13 \mathrm{~km}$ ), while six birds had foraging ranges averaging about $40 \mathrm{~km}$. The maximum foraging range was 59 and the maximum distance traveled was $165 \mathrm{~km}$. Maximum trip duration was $17 \mathrm{~h}$ (mean: $8 \mathrm{~h}$ ). An apparently bimodal distribution of foraging ranges affords new insight on the variable foraging behaviour of Black-legged Kittiwakes. Successful deployment of GPS loggers on kittiwakes holds much promise for telemetry studies on many other species of similar size and encourages this new approache for further studies.

Key words: Black-legged Kittiwake, Rissa tridactyla, foraging, Gulf of Alaska, telemetry 7

Seabirds spend most of their time at sea and are difficult to observe when not attending nests during breeding. Research is therefore biased toward land-based observations, with the at-sea biology of smaller species generally limited to counts of travelling and foraging birds from research vessels. Such studies are time- or area-restricted and unable to give detailed insights into the foraging behaviour of individuals (Weimerskirch et al. 2005). However, knowledge of foraging behaviour is essential to understanding both the ecological roles of seabirds and constraints acting upon them in marine ecosystems (Monaghan 1996; Wilson et al. 2002). The most productive and cost-effective way to study the flight and foraging behaviour of birds at sea employs electronic devices attached to individuals (Daunt et al. 2003; Garthe et al. 2007; Grémillet et al. 2004; Wilson et al. 2002). A variety of loggers 
and techniques have been developed in the last 40 years (Grémillet et al. 2000; Hamer et al. 2007; Weimerskirch and Wilson 2000). The newest tracking devices to come on line are GPS receivers, unlimited in range and capable of much higher resolution and accuracy than satellite transmitters or conventional radio telemetry (Hulbert and French 2001; Hünerbein et al. 2000). As with most new technologies, the first GPS data loggers were too heavy to deploy on all but very large-bodied seabirds such as albatrosses (Diomedeidae; (Waugh et al. 2005; Weimerskirch et al. 2002) and gannets (Sulidae; (Grémillet et al. 2004). The latest equipment, with package sizes in the range of 8-12 g, bring small and medium-sized seabirds (c. $300 \mathrm{~g}$ and larger) into the scope of possible applications.

Black-legged Kittiwakes (Rissa tridactyla), widely distributed in north temperate to arctic regions of the northern hemisphere, are the most abundant and one of the most thoroughly studied gull species in the world (Hatch et al. 2009). Detailed knowledge of foraging ecology is still lacking, however, as the species is highly pelagic, especially in winter, and foraging activity is difficult to observe. Kittiwakes stay closer to the coast while breeding, returning frequently to their nests to change incubation duties or deliver food to their chicks (Daunt et al. 2002; Hatch et al. 2009; Suryan et al. 2000), but even then their foraging trips often take them out of range of telemetry techniques that rely on fixed receiving equipment (Camphuysen 2005; Wanless et al. 1992). Kittiwake body mass averages about 430 $\mathrm{g}$ (Pacific) or $390 \mathrm{~g}$ (Atlantic) (Hatch et al. 2009), thus telemetry devices exceeding $20 \mathrm{~g}$ ( 5\% of their body weight) are not recommended (Caccamise and Hedin 1985; Calvo and Furness 1992; Phillips et al. 2003).

Kittiwakes are regarded as useful indicators of marine environmental change in the North Atlantic and North Pacific oceans (Frederiksen et al. 2007; Gill et al. 2002; Wanless et 
70 al. 2007). Many colonies have declined in numbers and productivity in the last 20-30 years

71 (Daunt et al. 2002; Hatch et al. 2009), probably because of reduced availability of their 72 principal food - small, schooling fish such as sand lance Ammodytes spp., capelin Mallotus

73 villosus, and juvenile cods (Gadidae) (Frederiksen et al. 2008; Harris and Wanless 1990;

74 Hatch et al. 1993b; Suryan et al. 2006), which they capture by dipping or surface plunging 75 (Hatch et al. 2009; Hoyo et al. 1996). As obligate surface feeders, kittiwakes are affected by 76 changes in both the abundance and vertical distribution of their food (Furness and Tasker 77 2000; Hatch et al. 1993b). Breeding kittiwakes may compensate for food shortage by 78 spending more time foraging and/or ranging farther from the colony, although this could have 79 disadvantages like higher vulnerability to nest site competition and predation on eggs or 80 chicks.

81 Here we report on the first use of miniature GPS data loggers to characterize the 82 foraging behaviour of Black-legged Kittiwakes. The work was conducted during the breeding 83 season of 2007 at Middleton Island in the north-central Gulf of Alaska, where population 84 monitoring and studies of breeding ecology, behaviour, and physiology have occurred since 85 the mid 1970s (Gill et al. 2002; Hatch et al. 1993b; Hatch et al. 1993a; Roberts and Hatch 86 1993). Data on foraging trip durations from this colony are available from one prior study 87 (Roberts and Hatch 1993) that employed direct observations of nest attendance in 1988, when 88 the colony was much larger than at present. There is concern about the status and viability of 89 this colony, which has declined more than $90 \%$ - from 83,000 pairs to 6,200 pairs — over 90 the last 26 years (Hatch et al. 2009). Understanding the decline will require a thorough 91 understanding of the birds' foraging habits, both during and outside the breeding season. 92 Knowledge of their foraging habits could reveal possible food shortness caused for example 
93 by competition with other seabird species, oceanographic anomalies, or fishing activities.

94

95

96

97

98

99

100

101

102

103

104

105

106 the wall beneath each window. Individuals chosen for logger deployment were actively

107 incubating or rearing chicks. Chick-rearing birds had one or two chicks aged 1-40 days. All

108 birds in the study were marked with a unique combination of steel and plastic colour bands

109 for individual recognition. Every nest was checked each morning for egg or chick status and 110 for the presence of adult birds.

111 Tracking devices were deployed between 1 July and 11 August 2007. We captured 14 112 adult kittiwakes and deployed GiPSy ${ }^{\circledR}$ data loggers (11 g; L 50 x W 22 x H 10 mm) 113 manufactured by TechnoSmart. The loggers were programmed to use a 5-min sampling 114 interval. GPS data stored in the device memory and used for the analysis included date, time, 115 latitude, longitude and speed. The devices were attached to feathers in the middle of the back 
116 with TESA $^{\circledR}$ tape (Wilson et al. 1997). Before deployment, each bird was weighed to the 117 nearest $5 \mathrm{~g}$ using a spring balance. The loggers were $2-3 \%$ of mean body mass (397 g, range 118 345-500 g). Mass was the only measurement taken upon first capture to minimize handling 119 time. Additional measurements (bill length, head-bill length, wing length) and banding were 120 taken upon recapture if data were not already available from previous studies. Measurements 121 were used to determine the sex of the birds (Jodice et al. 2000). Handling time (capture to 122 release) was approximately $10 \mathrm{~min}$ for deployment and 3-15 min for logger removal, banding, 123 and measurements as needed. In 28 captures and recaptures, 15 birds returned to their nest 124 within $15 \min$ ( 5 of them immediately), 4 birds within $31 \mathrm{~min}$, and 3 birds more than $1 \mathrm{~h}$ after 125 capture. Return time for 6 birds was undetermined due to a lack of nest observations. We 126 deployed 12 of the 14 loggers in the late afternoon or evening, which allowed us potentially to 127 capture information on nighttime foraging. We used 106 unmanipulated nests on the tower as 128 a control group to compare breeding success between equipped and non-equipped birds.

129 Flight paths were plotted in ArcView ${ }^{\circledR} 3.2$ from the positional data obtained. 130 Maximum foraging range was defined as the most distant position in a straight line from the 131 colony. Distance travelled refers to the summed distances between positions from start to end 132 locations of each foraging trip. Elapsed time from start to end of a trip is trip duration. Start 133 and end of a trip were defined using GPS data. Trips started when a positional fix was $300 \mathrm{~m}$ 134 away from the colony and subsequent positions were progressively farther away. In 135 calculating mean velocity (ground speed), we used only flight speeds greater than $10 \mathrm{~km} \mathrm{~h}^{-1}$, 136 excluding one outlier of $119 \mathrm{~km} \mathrm{~h}^{-1}$. Speeds less than $10 \mathrm{~km} \mathrm{~h}^{-1}$ were probably associated with 137 swimming or feeding (Weimerskirch et al. 2006).

138 Loggers were switched on at deployment - no delayed start was possible — and due 
139 to battery depletion or occasional large gaps in data collection, not all foraging trips were well

140 documented from start to finish. In calculating the mean maximum range, mean distance to

141 colony and mean trip duration we included only complete trips, but estimated values are also 142 reported for individual trips that were incomplete. The missing portion of a track line was 143 extrapolated directly back to the colony, which underestimates the distance travelled by an 144 unknown, but probably modest amount. Extrapolated track lines were then used to correct the 145 trip duration of incomplete trips using a mean flight speed of $33 \mathrm{~km} / \mathrm{h}$ (as measured in this 146 study; see below). Statistical analyses were carried out in R 2.8.0. and SPSS 11.5.

\section{$148 \quad$ Results}

All 14 instrumented birds were recaptured after 1-7 days. Two birds had shed the

151 logger by pulling out the feathers to which it was attached, although we did not observe birds 152 pecking at or trying to remove the logger. Two loggers failed to record data for unknown 153 reasons. Among the remaining sample of 10 kittiwakes, one bird incubated for nearly 2 days, 154 thus depleting its logger battery before leaving the nest. We used data from 9 successful 155 deployments (5 females, 4 males) for analysis of foraging patterns.

156 We obtained data for 16 foraging trips, 7 of which were complete (Table 1). Four birds 157 made one foraging trip, three made two trips, and two birds made three foraging trips during 158 the working period of the logger. Loggers recorded between 24 and 626 positional fixes 159 within a foraging trip (mean 123, SD 144).

160 The main foraging area was north of the colony, encompassing the continental shelf 161 area between Middleton Island and Prince William Sound (Fig. 2). Birds stayed mostly over 
162 waters less than $200 \mathrm{~m}$ deep. One bird made repeated visits to the shelf slope south and east of

163 the island but did not access the abyssal zone beyond (Fig. 2a, 2c). One bird visited the 164 nearshore area of Hinchinbrook Island at the entrance to Prince William Sound (92 km from 165 Middleton).

166 On 9 of the 16 foraging trips, which we categorize as "short" trips, kittiwakes stayed 167 within $13 \mathrm{~km}$ of the breeding site, in contrast to the remaining 7 trips — "long" trips that 168 exceeded $35 \mathrm{~km}$ from the colony (Fig. 3). Among the completed trips, the maximum range 169 from the colony was $59 \mathrm{~km}$, with a mean foraging range of $25.5 \mathrm{~km}$ (SD $22.2 \mathrm{~km}$ ). However, 170 one incomplete trip had a maximum range from the colony of at least $91.8 \mathrm{~km}$ (Table. 2). The 171 maximum total distance travelled by a kittiwake on a completed trip was $164.7 \mathrm{~km}$ (mean $17272.5 \mathrm{~km}$, SD $58.4 \mathrm{~km}$ ). When incomplete trips are taken into account the total maximum 173 distance travelled per trip was at least $306.3 \mathrm{~km}$.

174 Trip duration varied from $1.5 \mathrm{~h}$ to $16.8 \mathrm{~h}$ (mean $7.9 \mathrm{~h}, \mathrm{SD} 5.8 \mathrm{~h}$ ) for complete trips, 175 whereas one incomplete trip exceeded $33 \mathrm{~h}$ for incomplete trips. We found a positive 176 relationship between trip duration and total distance travelled per foraging for complete trips 177 trip (Spearman's $r_{s}=0.835, P<0.01$ ) but no significant relationship between foraging trip 178 duration and maximum distance to colony. Because of the small sample size of complete 179 foraging trips, statistical tests between males and females were not applicable.

180 Most trips occurred solely during daylight, but overnight trips were conducted by one 181 female and two males. In one instance the bird appeared to spend the night in or near another 182 portion of the colony on Middleton, whereas two overnight trips likely entailed foraging, as 183 the birds travelled far from the colony (Table 2). Nonetheless, the birds were mostly inactive 184 at night as indicated by rates of movement $<10 \mathrm{~km} \mathrm{~h}^{-1}$ (Fig. 2b). 

$\mathrm{km} \mathrm{h}^{-1}$ ) (Fig. 4). Kittiwakes spent only about a third (35\%) of their foraging trips engaged in

187 sustained directional flight. The remaining $65 \%$ of the time budget consisted of periods of 188 inactivity or other behaviours not characterized by directional flight (speeds $<10 \mathrm{~km} \mathrm{~h}^{-1}$ ).

We found no evidence that GPS loggers influenced breeding performance of the subjects. Breeding success (number of chicks fledged/number of eggs laid) of instrumented

191 birds (0.5) was similar to that of controls (0.44) and there were no differences in mean chick 192 mass between groups at three stages of development: newly hatched chicks, mid-chick stage 193 or chicks near fledging (Table 3).

\section{Discussion}

Foraging patterns were highly variable among Black-legged Kittiwakes sampled on Middleton Island in 2007, with a tendency towards bimodality in the distances travelled on

199 foraging trips. The longest and most far-ranging excursions were overnight trips, but even day 200 trips tended to range either less than $10 \mathrm{~km}$ or more than $40 \mathrm{~km}$ from the island. It may be that 201 shorter trips were used for chick-provisioning, while the longer trips were important for self202 feeding by adults, as suggested for chick-rearing Procellariiformes (Congdon et al. 2005; 203 Weimerskirch et al. 2001). Further study is needed to confirm that possibility in kittiwakes. 204 The disjunct distribution of foraging distances could also reflect prey distribution, as the main 205 prey of kittiwakes during chick rearing at Middleton, capelin and sand lance (Gill and Hatch 206 2002), may be available at different distances from the island. 
208 performed only during daylight (Coulson and Johnson 1993; Hamer et al. 1993; Roberts and

209 Hatch 1993). The importance of nighttime foraging was noted on Middleton in 1988, when

$21062 \%$ of overnight trips resulted in chick feeding upon return of the adult, while $35 \%$ of

211 daytime absences resulted in chick-feeding (Roberts and Hatch 1993). Overnight trips may in

212 general access distant foraging areas. Two of three overnight trips recorded in 2007 were

213 among the three most distant trips. Among birds tracked at night, the recorded flight speeds

$214<10 \mathrm{~km} \mathrm{~h}^{-1}$ indicated that hours of darkness were often spent in relative inactivity, probably

215 drifting on the surface, as was also observed by (Hamer et al. 1993) in Shetland. However,

216 birds "on water" might also engage in feeding by picking up small prey items, such as

217 euphausids or polychaetes, likely available at the surface at night.

218 Foraging ranges of breeding kittiwakes are variable from one location to another.

219 Ranges $( \pm$ SE) of $41 \pm 3 \mathrm{~km}$ (Shoup Bay), $26 \pm 5 \mathrm{~km}$ (Icy Bay), and $21 \pm 5 \mathrm{~km}$ (Eleanor

220 Island) were reported for three colonies in Prince William Sound (Ainley et al. 2003). The

221 maximum foraging distance from the Shoup Bay colony was $120 \mathrm{~km}$ (Suryan et al. 2000).

222 Values reported here for Middleton Island (mean range of all trips: $26 \mathrm{~km}$, maximum: $59 \mathrm{~km}$ )

223 are intermediate relative to Prince William Sound, whereas radio telemetry in Great Britain

224 (Sumburgh Head, Shetland) found that kittiwakes usually travelled more than $40 \mathrm{~km}$ from the

225 colony in 1990, beyond the range of receiving equipment (Wanless et al. 1992). In the

226 following year, more than $95 \%$ of foraging trips stayed within $5 \mathrm{~km}$ of the Sumburgh Head

227 colony, a reversal attributed to improved food availability (Hamer et al. 1993). Elsewhere in

228 Britain, maximum ranges of $73 \pm 9 \mathrm{~km}$ from the Isle of May and $55.5 \mathrm{~km}$ from the Farne

229 Islands were estimated from flight duration and speed (Daunt et al. 2002; Pearson 1968).

230 Kittiwakes breeding at Helgoland in the German Bight were seen at a distance of 10-35 km 
231 from the colony (aerial and ship based transect counts). Only single birds were observed at 232 distances up to 70-80 km (Dierschke et al. 2004). Those relatively short foraging distances 233 may be explained by low competition for prey - good feeding conditions around the island, 234 small size of the colony, and its isolation from other colonies of the same species

235 Our mean trip duration $(7.9 \mathrm{~h})$ was longer than that observed by (Roberts and Hatch 236 1993) on Middleton Island in 1988 (mean $4.1 \mathrm{~h}$ for daytime trips that culminated in chick237 feeding). Shorter trips are also reported from other colonies in Alaska and in Great Britain. 238 Mean trip durations of 3.4-6 h were found among kittiwakes in Prince William Sound (Ainley 239 et al. 2003; Suryan et al. 2000). Kittiwakes from the Isle of May spent $6.1 \mathrm{~h}$ (Humphreys et al. 240 2006) and $5.5 \mathrm{~h}$ (Daunt et al. 2002) at sea, and foraging trips were shorter still in two other 241 Scottish colonies - $3.4 \mathrm{~h}$ (Hamer et al. 1993) and $2.8 \mathrm{~h}$ (Coulson and Johnson 1993). 242 However, trip durations averaged more than $6 \mathrm{~h}$ during a year of reduced prey availability 243 (Hamer et al. 1993; Wanless et al. 1992). Our mean trip duration of nearly $8 \mathrm{~h}$ therefore 244 suggests poor food availability near Middleton Island in 2007. Flexible time budgets, as a 245 means of coping with low food availability, are also known from other colonies of kittiwakes 246 and murres (Uria lomvia and U. aalge) in Alaska (Harding et al. 2007; Kitaysky et al. 2000). 247 With one exception, kittiwakes foraged only in a northerly direction from the colony, 248 over the continental shelf and within the 200-m depth contour. We expected the shelf edge, a 249 potentially rich feeding habitat close to the island, to be a greater attraction than it was. 250 However, upwelling along the shelf edge is not as strong in summer as in winter (Weingartner 251 et al. 2005), which may explain the absence of kittiwakes in that area during July and August. 252 Observations on diet suggest a different situation in April, prior to egg-laying. Prey 253 regurgitated by kittiwakes in the first several weeks after returning to Middleton Island in 
254 spring consist mostly of lanternfishes (Myctophidae) and small squids (S. A. Hatch, unpubl.

255 data). The birds presumably obtain this prey from deep ocean habitat of the continental slope

256 and abyssal ocean south of the island. Myctophids and squids are important components of 257 the mesopelagic community that migrate vertically to the ocean surface at night (Beamish et 258 al. 1999; Sinclair and Stabeno 2002). Myctophids, in particular, are high-energy prey (Van 259 Pelt et al. 1997) whose availability to kittiwakes before and during early breeding stages on 260 Middleton is thought to influence breeding success (Gill and Hatch 2002). Such prey are seen 261 also during incubation in some years (Gill and Hatch 2002). In this study we sampled two 262 birds late in incubation, one of which went to the shelf edge east of Middleton while the other 263 made the most distant foraging trip observed, on a northwesterly heading to Hinchinbrook 264 Island. More sampling is needed to clarify the relative importance and seasonality of deep 265 ocean versus neritic foraging by kittiwakes from Middleton.

266 Pennycuick $(1987 ; 1997)$ and Götmark (1980) observed air speeds for kittiwakes of 267 about 47 and $54 \mathrm{~km} \mathrm{~h}^{-1}$, respectively. Our observed mean flight speed of $33 \mathrm{~km} \mathrm{~h}^{-1}$ was lower 268 than those speeds and matches better with the minimum power speed of Pennycuick (1987; 269 1997). But flight speeds varied greatly during foraging trips. Speed of flight to and from 270 foraging areas ranged from about $20-60 \mathrm{~km} \mathrm{~h}^{-1}$, while birds searching for food had flight 271 speeds up to $20 \mathrm{~km} \mathrm{~h}^{-1}$. It seems that birds changed between minimum power and maximum 272 range speeds (Pennycuick 1987, 1997) while flying to and coming back from foraging areas. 273 Whether this behaviour was weather dependent should be investigated.

274 In conclusion, we affirm the utility of GPS data loggers in elucidating the movements 275 and marine habitat use of seabirds previously excluded from such investigations because of 276 their small body size. Kittiwakes exhibited flexible foraging behaviour-short and long 
277 foraging trips that appeared to change in relative frequencies over the course of chick rearing.

278 Although the sample was limited to 16 foraging trips, seven of them complete, we gained 279 much insight into the foraging behaviour of Black-legged Kittiwakes from Middleton Island. 280 Nearly all foraging trips were over the continental shelf, in northerly direction of the colony. 281 Thus, we believe the sample typifies the behaviour of most birds in this colony, but further 282 investigations are desirable. Interannual and within-season variation have yet to be fully 283 investigated.

284 Future applications of this powerful new technology promise many valuable insights 285 on the foraging strategies of kittiwakes and other oceanic birds of similar size. GPS data 286 loggers are able to track seabirds at distances from the colony that are out of range of 287 conventional radio telemetry. In addition, they are unaffected by weather conditions, an 288 important constraint on ship or aerial transect counts.

\section{Zusammenfassung}

GPS-Logger offenbaren Nahrungssuchstrategien der Dreizehenmöwen

295 Die Dreizehenmöwe (Rissa tridactyla) ist die weltweit häufigste Möwenart, aber viele

296 Populationen haben in den letzten Jahren abgenommen, was vermutlich auf 297 Nahrungsverknappung zurückzuführen ist. Dreizehenmöwen suchen ihre Nahrung an der 298 Wasseroberfläche und können deshalb geringe Nahrungsverfügbarkeit nur durch ein 299 Ausweiten ihres Nahrungssuchgebietes und / oder einen erhöhten Zeitaufwand kompensieren. 
300 Diese Möwenart ist schon in vielen Aspekten ihrer Biologie untersucht wurden, aber durch

301 ihre weiten Nahrungssuchflüge und die Einschränkungen durch die konventionelle

302 Radiotelemetrie konnten diesen Aktivitäten bisher nur wenig untersucht werden. Die 303 Entwicklung von GPS-Loggern schreitet schnell voran. Mit neuen Geräten, die nur noch 8 g 304 wiegen, ist es jetzt auch möglich relativ kleine Seevogelarten, wie die Dreizehenmöwe, mit 305 dieser Technologie auszustatten und zu untersuchen. Hier präsentieren wir erste Ergebnisse 306 der GPS-Loggereinsätze auf Dreizehenmöwen aus dem Jahr 2007 aus dem Nordpazifik. Mit 307 Ausnahme von einem Tier sind alle Vögel in der neritischen Zone nördlich der Insel auf 308 Nahrungssuche gegangen. Drei Vögel suchten nur in unmittelbarer Nähe zur Kolonie (< $30913 \mathrm{~km}$ ) nach Nahrung, während sechs weitere Tiere eine durchschnittliche Entfernung von $31040 \mathrm{~km}$ zeigten. Die maximale Entfernung zur Kolonie betrug $59 \mathrm{~km}$ und die maximale 311 zurückgelegte Distanz während eines Nahrungssuchfluges betrug $165 \mathrm{~km}$. Der längste 312 Nahrungssuchflug dauerte 17 h (Mittelwert: 8 h). Die maximalen Distanzen zur Kolonie der 313 Nahrungssuchflüge machen eine bimodale Verteilung sichtbar, was neue Einsichten in das 314 variable Nahrungssuchverhalten von Dreizehenmöwen liefert. Die erfolgreiche Ausstattung 315 von Dreizehenmöwen mit GPS-Loggern verspricht auch Erfolg mit Telemetriestudien bei 316 vielen anderen Arten ähnlicher Größe und gibt neue Ansätze für weitere Untersuchungen.

\section{Acknowledgements}

320 This project was funded by the German Science Foundation (DFG GA 617/5-1). We thank

321 Hilger Lemke for major assistance with the field work and all others who helped us during the 322 study on Middleton Island. Nele Markones, Philipp Schwemmer, and four anonymous 
323 reviewers made useful comments on an earlier draft of the manuscript. Haglöfs® sponsored

324 some of the equipment for this study. Mention of trade names is for descriptive purposes only 325 and does not imply endorsement by the U.S. Government. The study was approved and 326 carried out under Alaska State and U.S. Federal Fish and Wildlife permits.

\section{References}

330 Ainley DG, Ford RG, Brown ED, Suryan RM and Irons DB (2003) Prey resources, competition, and geographic structure of Kittiwake colonies in Prince William Sound. Ecology 84: 709-723

333 Beamish RJ, Leask KD, Ivanov OA, Balanov AA, Orlov AM and Sinclair B (1999) The ecology, distribution, and abundance of midwater fishes of the Subarctic Pacific gyres. Prog Oceanogr 43: 399-442

336 Caccamise DF and Hedin RS (1985) An Aerodynamic Basis For Selecting Transmitter Loads In Birds. Wilson Bull 97: 306-318

338 Calvo B and Furness RW (1992) A review of the use and the effects of marks and devices on birds. Ring Migr 13: 129-151

340 Camphuysen CJ (2005) Understanding marine foodweb processes: An ecosystem approach to sustainable sandeel fisheries in the North Sea. Impress Final Report. Royal Netherlands Institute for Sea Research, Texel

343 Congdon BC, Krockenberger AK and Smithers BV (2005) Dual-foraging and co-ordinated provisioning in a tropical Procellariiform, the wedge-tailed shearwater. Mar Ecol Prog Ser 301: 293-301 
346 Coulson JC and Johnson MP (1993) The attendance and absence of adult Kittiwakes Rissa 347 tridactyla from the nest site during the chick stage. Ibis 135 : $372-378$

348 Daunt F, Benvenuti S, Harris MP, Dall'Antonia L, Elston DA and Wanless S (2002) Foraging 349 strategies of the black-legged kittiwake Rissa tridactyla at a North Sea colony: 350 evidence for a maximum foraging range. Mar Ecol Prog Ser 245: 239-247

351 Daunt F, Peters G, Scott B, Grémillet D and Wanless S (2003) Rapid-response recorders 352 353 reveal interplay between marine physics and seabird behaviour. Mar Ecol Prog Ser 255: $283-288$

354 Dierschke V, Garthe S and Markones N (2004) Aktionsradien Helgoländer Dreizehenmöwen Rissa tridactyla und Trottellummen Uria aalge während der Aufzuchtphase. Vogelwelt 125: 11-19

Frederiksen M, Mavor RA and Wanless S (2007) Seabirds as environmental indicators: the 358 advantages of combining data sets. Mar Ecol Prog Ser 352: 205-211

Frederiksen M, Jensen H, Daunt F, Mavor RA and Wanless S (2008) Differential effects of a

Furness RW and Tasker ML (2000) Seabird-fishery interactions: quantifying the sensitivity of 363 seabirds to reductions in sandeel abundance, and identification of key areas for sensitive seabirds in the North Sea. Mar Ecol Prog Ser 202: 253-264

365 Garthe S, Montevecchi WA and Davoren GK (2007) Flight destinations and foraging 366 behaviour of northern gannets (Sula bassana) preying on a small forage fish in a lowarctic ecosystem. Deep Sea Res Part II 54: 311-320 
368 Gill VA and Hatch SA (2002) Components of productivity in Black-legged Kittiwakes Rissa 369 tridactyla: response to supplemental feeding. J Avian Biol 33: 113-126

370 Gill VA, Hatch SA and Lanctot RB (2002) Sensitivity of breeding parameters to food supply in Black-legged Kittiwakes Rissa tridactyla. Ibis 144: 268-283

Götmark F (1980) Foraging flights of Kittiwakes-some functional aspects. Vår Fågelvärld 39: $65-74$

Grémillet D, Storch S and Peters G (2000) Determining food requirements in marine top predators: a comparison of three independent techniques in Great Cormorants, Phalacrocorax carbo carbo. Can J Zool 78: 1567-1579

Grémillet D, Omo GD, Ryan PG, Peters G, Ropert-Coudert Y and Weeks SJ (2004) Offshore diplomacy, or how seabirds mitigate intra-specific competition: a case study based on GPS tracking of Cape Gannets from neighbouring colonies. Mar Ecol Prog Ser 268: 265-279

381 Hamer KC, Monaghan P, Uttley JD, Walton P and Burns MD (1993) The influence of food supply on the breeding ecology of Kittiwakes Rissa tridactyla in Shetland. Ibis 135: MP and Wanless S (2007) Annual variation in diets, feeding locations and foraging behaviour of gannets in the North Sea: flexibility, consistency and constraint. Mar Ecol Prog Ser 338: 295-305 $255-263$

Hamer KC, Humphreys EM, Garthe S, Hennicke J, Peters G, Grémillet D, Phillips RA, Harris 
391 Harris MP and Wanless S (1990) Breeding Success Of British Kittiwakes Rissa tridactyla In 1986-88 - Evidence For Changing Conditions In The Northern North Sea. J Appl Ecol 27: $172-187$

394 Hatch SA, Roberts BD and Fadely BS (1993a) Adult survival of Black-legged Kittiwakes Rissa tridactyla in a Pacific colony. Ibis 135: 247-254

396 Hatch SA, Byrd GV, Irons DB and G. L. Hunt J (1993b) Status and ecology of kittiwakes (Rissa tridactyla and R. brevirostris) in the North Pacific. Canadian Wildlife Service, Ottawa, ON

Hatch SA, Robertson GJ and Baird PH (2009) Black-legged Kittiwake (Rissa tridactyla). In: Poole A (ed) The Birds of North America Online. Cornell Lab of Ornithology, Ithaca

Hoyo Jd, Elliott A and Sargatal J (1996) Handbook of the Birds of the World. Vol. 3. Lynx Edictions, Barcelona

403

404

405

406

407

408

409
Hulbert IAR and French J (2001) The accuracy of GPS for wildlife telemetry and habitat mapping. J Appl Ecol 38: 869-878

Humphreys EM, Wanless S and Bryant DM (2006) Stage-dependent foraging in breeding black-legged kittiwakes Rissa tridactyla: distinguishing behavioural responses to intrinsic and extrinsic factors. J Avian Biol 37: 436-446

Hünerbein Kv, Hamann HJ, Ruter E and Wiltschko W (2000) A GPS-based system for recording the flight path of birds. Naturwissenschaften 87: 278-279

Jodice PGR, Lanctot RB, Gill VA, Roby DD and Hatch SA (2000) Sexing Adult Blacklegged Kittiwakes by DNA, Behavior, and Morphology. Waterbirds 23: 405-415 
412 Kitaysky AS, Jr GLH, Flint EN, Rubega MA and Decker MB (2000) Resource allocation in 413 breeding seabirds: responses to fluctuations in their food supply. Mar Ecol Prog Ser $414 \quad 206: 283-296$

415 Monaghan P (1996) Relevance of the behaviour of seabirds to the conservation of marine $416 \quad$ environments. Oikos 77: 227-237

417 Pearson TH (1968) The feeding biology of sea-bird species breeding on the Farne Islands, $418 \quad$ Northumberland. J Anim Ecol 37: 521-552

419 Pennycuick CJ (1987) Flight of Auks (Alcidae) and other northern seabirds compared with 420 southern Precellariiformes: ornithodolite observations. J Exp Biol 128: 335-347

421 Pennycuick CJ (1997) Actual and 'optimum' flight speeds: field data reassessed. J Exp Biol 422 2000: $2355-2361$

423 Phillips RA, Xavier JC and Croxall JP (2003) Effects of satellite transmitters on albatrosses 424 and petrels. Auk 120: 1082-1090

Roberts BD and Hatch SA (1993) Behavioral ecology of Black-legged Kittiwakes during chick rearing in a failing colony. Condor 95: 330-342

427 Sinclair EH and Stabeno PJ (2002) Mesopelagic nekton and associated physics of the 428 southeastern Bering Sea. Deep Sea Res Part II 49: 6127-6145

Suryan RM, Irons DB and Benson J (2000) Prey switching and variable foraging strategies of Black-legged Kittiwakes and the effect on reproductive success. Condor 102: 374-384

431 Suryan RM, Irons DB, Brown ED, Jodice PGR and Roby DD (2006) Site-specific effects on 432 productivity of an upper trophic-level marine predator: Bottom-up, top-down, and mismatch effects on reproduction in a colonial seabird. Prog Oceanogr 68: 303-328 
434 Van Pelt TI, Piatt JF, Lance BK and Roby DD (1997) Proximate composition and energy 435 density of some North Pacific forage fishes. Comp Biochem Physiol A-Mol Integr $436 \quad$ Physiol 118: 1393-1398

437 Wanless S, Monaghan P, Uttley JD, Walton P and Morris JA (1992) A radio-tracking study of 438 kittiwakes (Rissa tridactyla) foraging under suboptimal conditions. In: Priede IG and 439 Swift SM (eds) Wildlife telemetry. Remote monitoring and tracking of animals. Ellis $440 \quad$ Horwood, New York, pp 581-590

441 Wanless S, Frederiksen M, Daunt F, Scott BE and Harris MP (2007) Black-legged kittiwakes 442 as indicators of environmental change in the North Sea: Evidence from long-term studies. Prog Oceanogr 72: 30-38

444 Waugh S, Filippi D, Fukuda A, Suzuki M, Higuchi H, Setiawan A and Davis L (2005) Foraging of royal albatrosses, Diomedea epomophora, from Otago Peninsula and its relationships to fisheries. Can J Fish Aquat Sci 62: 1410-1421

Weimerskirch H and Wilson RP (2000) Oceanic respite for Wandering Albatrosses. Nature 406: $955-956$

Weimerskirch H, Chastel O, Cherel Y, Henden J-A and Tveraa T (2001) Nest attendance and 450 foraging movements of northern fulmars rearing chicks at Bjørnøya Barents Sea. Polar Biol 24: 83-88

Weimerskirch H, Bonadonna F, Bailleul F, Mabille G, Dell'Omo G and Lipp H-P (2002) GPS 453 tracking of foraging Albatrosses. Science 295: 1259

454 Weimerskirch H, Corre ML, Jaquemet S and Marsac F (2005) Foraging strategy of a tropical 455 seabird, the red-footed booby, in a dynamic marine environment. Mar Ecol Prog Ser 288: 251-261 
457 Weimerskirch H, Corre ML, Ropert-Coudert Y, Kato A and Marsac F (2006) Sex-specific 458 foraging behaviour in a seabird with reversed sexual dimorphism: the red-footed 459 booby. Oecologia 146: 681-691

460 Weingartner TJ, Danielson SL and Royer TC (2005) Freshwater variability and predictability 461 in the Alaska Coastal Current. Deep Sea Res Part II 52: 169-191

462 Wilson RP, Pütz K, Peters G, Culik B, Scolaro JA, Charrassin J-B and Ropert-Coudert Y 463 (1997) Long-term attachment of transmitting and recording devices to penguins and 464 other seabirds. Wildl Soc Bull 25: 101-106

465 Wilson RP, Grémillet D, Syder J, Kierspel MAM, Garthe S, Weimerskirch H, Schaefer-Neth 466 C, Scolaro JA, Bost C-A, Plötz J and Nel D (2002) Remote-sensing systems and 467 seabirds: their use, abuse and potential for measuring marine environmental variables. 468 Mar Ecol Prog Ser 228: 241-261

469 470 
Table 1. Summary of deployments of GPS data loggers attached to Black-legged Kittiwakes on Middleton Island, Alaska during the breeding season in 2007.

\begin{tabular}{|c|c|c|c|c|c|c|c|}
\hline \multirow[b]{2}{*}{ Bird no. } & \multirow[b]{2}{*}{ Nest } & \multirow[b]{2}{*}{ Sex } & \multirow[b]{2}{*}{ Brood stage } & \multicolumn{2}{|c|}{ Date } & \multicolumn{2}{|c|}{ No. of trips } \\
\hline & & & & deployment & recapture & complete & incomplete \\
\hline 1 & D-15 & female & incubating & 02 Jul & 04 Jul & \multicolumn{2}{|c|}{ battery empty before left the nes } \\
\hline 2 & B-10 & male & incubating & $05 \mathrm{Jul}$ & $10 \mathrm{Jul}$ & 0 & 1 \\
\hline 3 & B-6 & male & incubating & $08 \mathrm{Jul}$ & $10 \mathrm{Jul}$ & 0 & 2 \\
\hline 4 & D-15 & male & incub./chick rear. & $11 \mathrm{Jul}$ & $14 \mathrm{Jul}$ & \multicolumn{2}{|c|}{ no data recorded } \\
\hline 5 & B-14 & female & chick rearing & $11 \mathrm{Jul}$ & $14 \mathrm{Jul}$ & \multicolumn{2}{|c|}{ no data recorded } \\
\hline 6 & D-17 & female & chick rearing & $14 \mathrm{Jul}$ & $16 \mathrm{Jul}$ & 1 & 2 \\
\hline 7 & B-16 & female & chick rearing & $14 \mathrm{Jul}$ & $17 \mathrm{Jul}$ & \multicolumn{2}{|c|}{ logger lost } \\
\hline 8 & D-4 & male & chick rearing & $17 \mathrm{Jul}$ & 01 Jul & 1 & 0 \\
\hline 9 & D-13 & male & chick rearing & $19 \mathrm{Jul}$ & $20 \mathrm{Jul}$ & 1 & 0 \\
\hline 10 & B-4 & female & chick rearing & $21 \mathrm{Jul}$ & $23 \mathrm{Jul}$ & 1 & 1 \\
\hline 11 & D-3 & female & chick rearing & $25 \mathrm{Jul}$ & $27 \mathrm{Jul}$ & 1 & 1 \\
\hline 12 & $\mathrm{D}-2$ & female & chick rearing & $27 \mathrm{Jul}$ & $28 \mathrm{Jul}$ & 0 & 1 \\
\hline 13 & B-4 & male & chick rearing & $29 \mathrm{Jul}$ & 05 Aug & \multicolumn{2}{|c|}{ logger lost } \\
\hline 14 & $\mathrm{C}-1$ & female & chick rearing & $08 \mathrm{Aug}$ & 11 Aug & 2 & 1 \\
\hline
\end{tabular}


Table 2. Foraging behaviour of Black-legged Kittiwakes from Middleton Island, Alaska during the breeding season in 2007. Range indicates

\begin{tabular}{|c|c|c|c|c|c|c|c|}
\hline Bird no. & Sex & Brood stage & Trip duration (h) & Range (km) & Total dist. travelled (km) & $\begin{array}{l}\text { Complete/ } \\
\text { incomplete }\end{array}$ & $\begin{array}{c}\text { Diel period of trip } \\
\text { day only (d) / overnight (n) } \\
\end{array}$ \\
\hline 2 & male & incubating & 6.5 & 9.8 & 51.2 & incomplete & $\mathrm{d}$ \\
\hline \multirow[t]{2}{*}{3} & male & incubating & 2.1 & 1.4 & 3.9 & incomplete & $\mathrm{d}$ \\
\hline & & & 33.0 & 91.8 & 306.3 & incomplete & $\mathrm{n}$ \\
\hline \multirow[t]{3}{*}{6} & female & chick rearing & 2.5 & 3.8 & 9.7 & incomplete & $d$ \\
\hline & & & 12.8 & 59.0 & 164.7 & complete & $\mathrm{n}$ \\
\hline & & & 4.6 & 47.2 & 100.5 & incomplete & d \\
\hline 8 & male & chick rearing & 16.8 & 35.2 & 92.5 & complete & $\mathrm{n}$ \\
\hline 9 & male & chick rearing & 7.2 & 49.5 & 129.7 & complete & $\mathrm{d}$ \\
\hline \multirow[t]{2}{*}{10} & female & chick rearing & 2.1 & 4.9 & 14.7 & complete & $d$ \\
\hline & & & 8.8 & 63.6 & 179.0 & incomplete & $\mathrm{d}$ \\
\hline \multirow[t]{2}{*}{11} & female & chick rearing & 3.8 & 5.6 & 18.7 & incomplete & d \\
\hline & & & 4.2 & 12.5 & 35.0 & complete & $\mathrm{d}$ \\
\hline 12 & female & chick rearing & 6.9 & 36.1 & 121.4 & incomplete & $\mathrm{d}$ \\
\hline \multirow[t]{3}{*}{14} & female & chick rearing & 4.1 & 3.0 & 6.7 & incomplete & $d$ \\
\hline & & & 1.5 & 6.4 & 15.5 & complete & d \\
\hline & & & 10.4 & 10.9 & 55.4 & complete & d \\
\hline
\end{tabular}


496 Table 3. Comparison of breeding success (number of chicks/number of eggs laid) and chick 497 growth at three stages of development between logger birds and non equipped Black-legged 498 Kittiwakes in 2007 on Middleton Island, Alaska. Numbers in parentheses are sample sizes.

499

\begin{tabular}{|crrrc|}
\hline & Logger birds & Non-equipped birds & Statistics (GLM) \\
\hline no. chicks / no. eggs laid & $0.5 \quad(\mathrm{n}=13)$ & 0.4 & $(\mathrm{n}=95)$ & $t=0.617, P=0.538$ \\
mean chick mass in g (0 days) & $36.5(\mathrm{n}=16)$ & 35.7 & $(\mathrm{n}=85)$ & $t=0.664, P=0.508$ \\
mean chick mass in g (20 days) & $300.3 \quad(\mathrm{n}=12)$ & 319.3 & $(\mathrm{n}=75)$ & $t=1.107, P=0.271$ \\
mean chick mass in g (35 days) & $413.9 \quad(\mathrm{n}=8)$ & 422.0 & $(\mathrm{n}=69)$ & $t=-0.538, P=0.592$ \\
\hline
\end{tabular}

500

501

502

503

504

505

506

507 
$\underline{\text { Figure Legends }}$

510 Figure 1. Study area in the Gulf of Alaska showing the locations of Middleton Island and

511 Prince William Sound (PWS). Middleton lies about $80 \mathrm{~km}$ south of the Alaska mainland.

512 Depth contours indicate the position of the continental slope.

514 Figure 2. Foraging tracks of Black-legged Kittiwakes from Middleton Island during the 515 breeding season in 2007. Maps show Middleton Island (MDO), the entrance to Prince 516 William Sound (PWS), Hinchinbrook Island (HI), and bathymetry in meters. (a) All foraging 517 trips (16) performed by nine instrumented birds. (b) Two long-distance, overnight trips (two 518 different birds) shown in more detail. Circles indicate resting areas at night, white dots are 519 positional fixes obtained by the GPS logger, and arrows indicate direction of movement. (c) 520 Two examples of shorter trips shown in more detail. Symbology as in (b).

522 Figure 3. Maximum foraging distances $(\mathrm{km})$ for all recorded foraging trips from Middleton 523 Island in 2007, sorted chronologically.

525 Figure 4. Flight speeds of Black-legged Kittiwakes from Middleton Island recorded by GPS-

526 data loggers during the breeding season in 2007. Flight speeds $\leq 10 \mathrm{~km} \mathrm{~h}^{-1}$ are not depicted 527 for reasons explained in the text. 


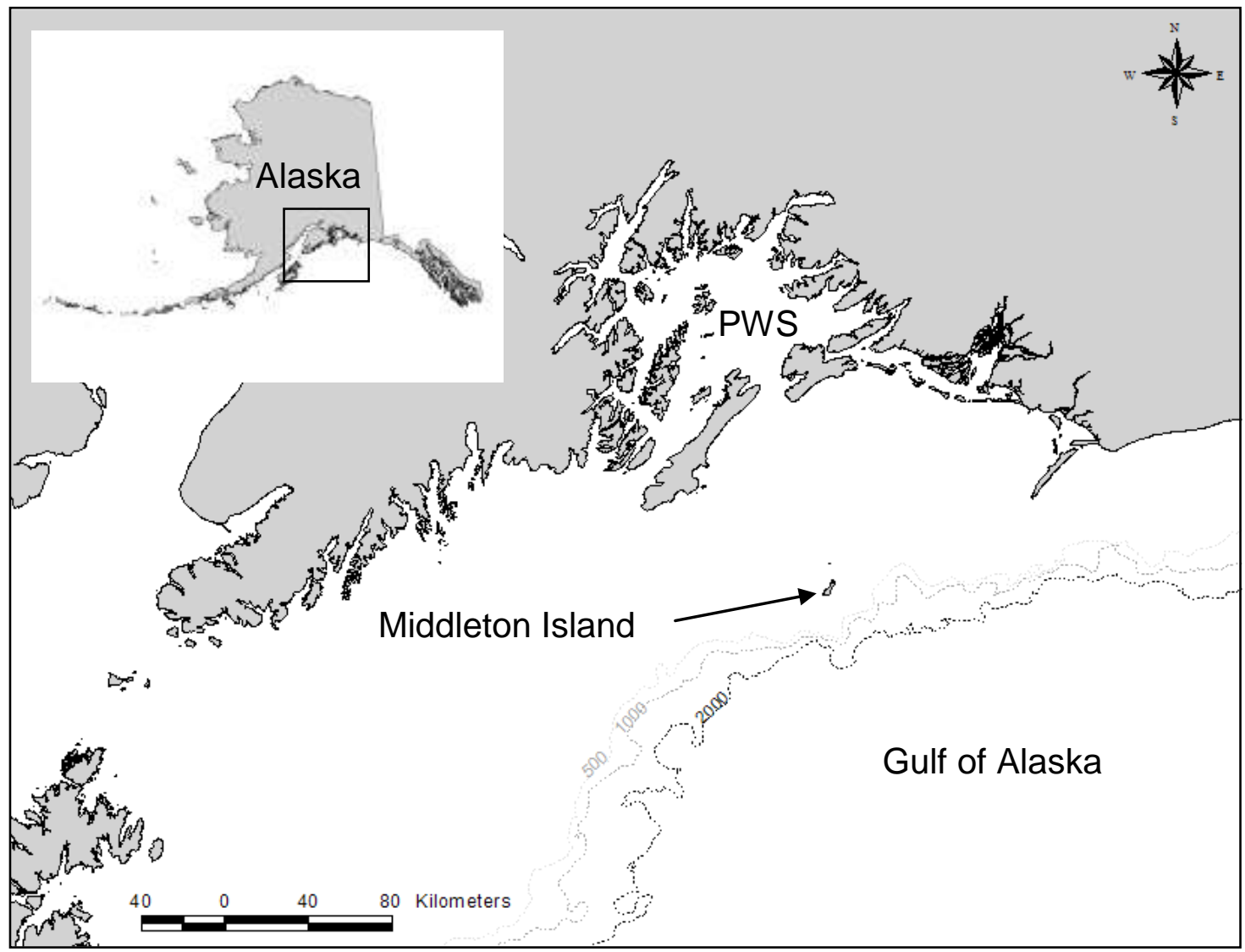

Figure 1 

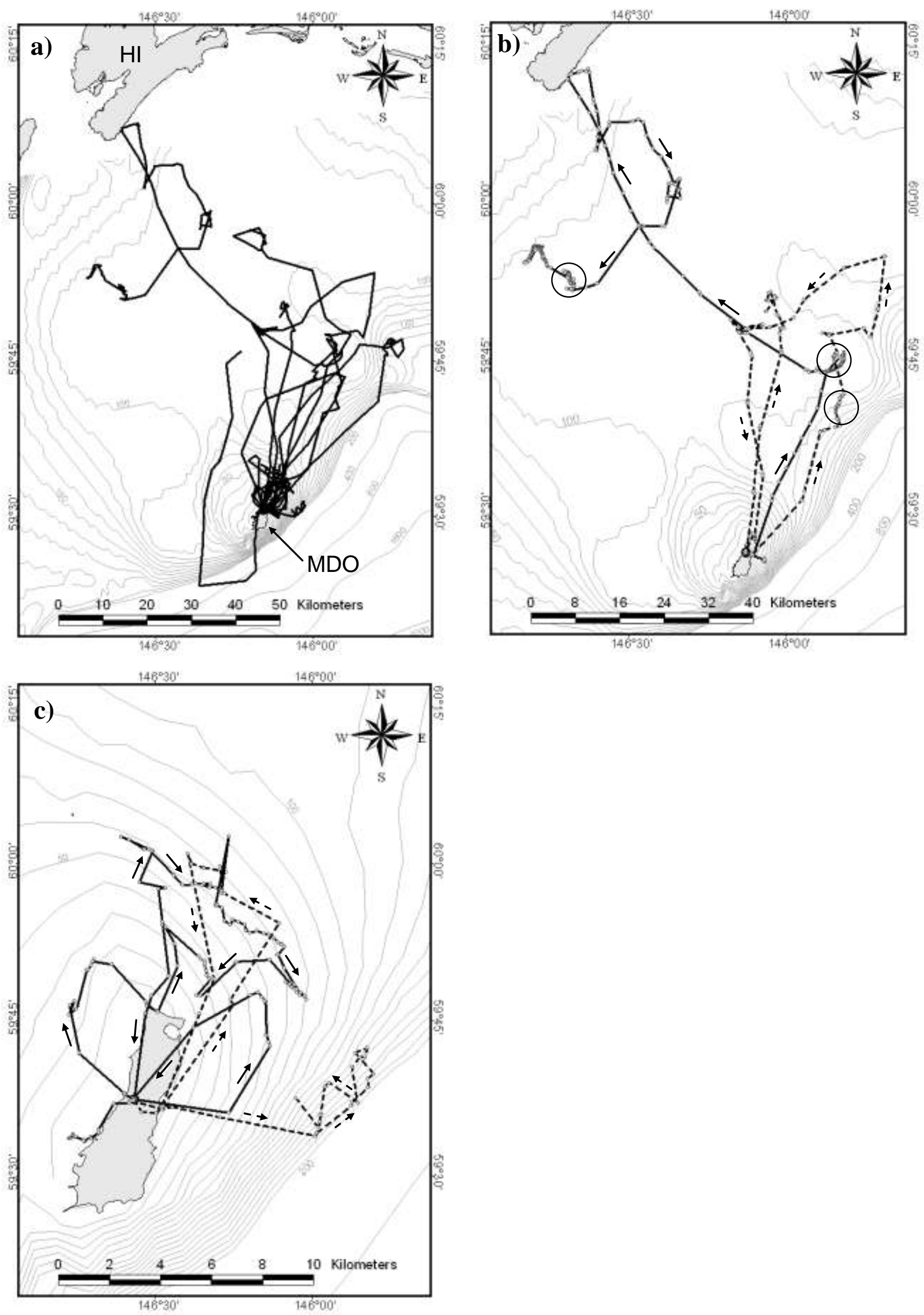

Figure 2 


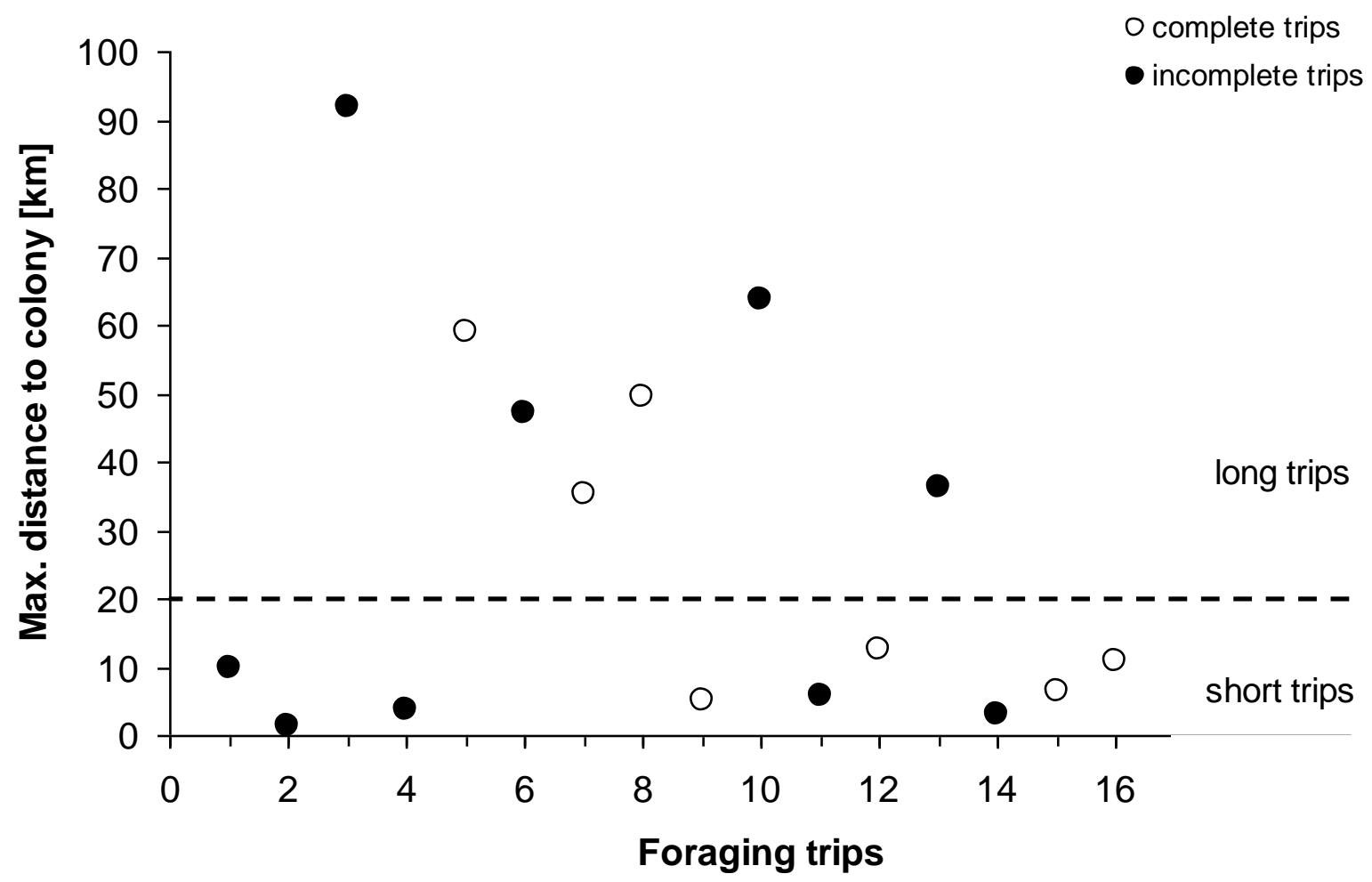

Figure 3 
